\title{
MENINGKATKAN KETERAMPILAN PROSES SAINS DAN HASIL BELAJAR BIOLOGI MELALUI MODEL PEMBELAJARAN EXPERIENTIAL LEARNING SISWA KELAS VIIA SMP NEGERI 1 GEDUNG AJI
}

\author{
Sulis Anjarwati \\ Universitas Nahdlatul Ulama Lampung \\ E-mail: sulis.anjarwati.sa@g mail.com
}

\begin{abstract}
Learning biology emphasizes providing direct leaming experiences to develop science process skills that should ideally be studied scientifically. The problem underlying this study is the lack of science process skills and poor student learning outcomes. In an effort to overcome these researchers used a model of experiential leaming to enhance the learning of science process skills and student learning outcomes, so that students are directly involved in discovering and understanding yourself. This study aims to improve science process skills and learning outcomes biology students using experiential learning model learning in class VIIA SMP Negeri 1 Aji building totaling 32 students. This research is Classroom Action Research (CAR) with 2 cycles each consisting of 3 sessions. Data science process skills acquired by students using observation sheet at each meeting, and student learning outcomes data obtained by giving a test at the end of each cycle. The results showed that: 1) the biology of learning using experiential learning model learning improve science process skills VIIA graders of SMP Negeri 1 Aji Building Academic Year 2012/2013 on materials Characteristics Being of Life. For the average percentage of students 'science process skills in pre-PTK by $24.19 \%$ after learning with experiential learning instructional model the average percentage of students' science process skills in the first cycle to the second cycle increased by $11.46 \%$ and has reached the target researchers that the percentage of $60 \% \leq M<80 \%$ or higher qualification, 2) learning biology using experiential learning model learning improve student learning outcomes VIIA grade SMP Negeri 1 Aji Building Academic Year 2012/2013 on materials Characteristics Being of Life. Students who completed their study or exceed KKM $\geq 65$ on the pre-PTK by $25.81 \%$ after leaming with experiential learning model learning of students who pass their learning on the first cycle to the second cycle increased by $9.37 \%$ and have achieved the target of researchers that students who study completed $\geq 75 \%$.
\end{abstract}

Kata kunci: model pembelajaran experiential learning, keterampilan proses sains, hasil belajar

Salah satu permasalahan yang dihadapi dunia pendidikan adalah rendahnya kualitas hasil dan proses belajar yang dicapai siswa. Rendahnya kualitas hasil belajar ditandai oleh pencapaian prestasi belajar yang belum memenuhi standar kompetensi seperti tuntutan kurikulum. Dalam setiap mata pelajaran termasuk mata pelajaran biologi, proses belajar yang dilakukan siswa terbatas pada penguasaan materi pelajaran. Padahal menurut tuntutan kurikulum yang berlaku siswa diharapkan bukan hanya sekedar dapat mengakumulasi pengetahuan akan tetapi, diharapkan dapat mencapai kompetensi, yakni perpaduan pengetahuan, sikap, dan keterampilan yang direfleksikan dalam kehidupan sehari-hari. Hampir seluruh siswa menganggap bahwa proses belajar biologi adalah proses 
menghafal materi pelajaran. Pembelajarannya hanya mendengar, mencatat, dan menghafal sesuai dengan sumber belajar yang ditentukan. Asumsi ini yang kemudian mendorong siswa untuk menempatkan mata pelajaran biologi sebagai mata pelajaran hafalan yang membosankan sebagian siswa.

Berdasarkan hasil observasi, pembelajaran biologi yang telah dilaksanakan sudah baik seperti penggunaan model pembelajaran yang sudah bervariasi tetapi selama pembelajaran hanya sebagian siswa yang aktif karena karakteristik yang berbeda-beda. Keterampilan proses sains perlu ditingkatkan karena dari hasil observasi diketahui, bahwa
Akibatnya, proses belum semua aspek keterampilan proses sains yang dilatih oleh guru tercapai atau masih terlihat begitu rendah sehingga mengakibatkan hasil belajar siswa masih rendah. Keterampilan proses sains yang ingin ditingkatkan pada penelitian ini adalah, keterampilan mengajukan pertanyaan, keterampilan mengkomunikasikan, keterampilan mengamati, dan keterampilan membuat kesimpulan. Hal ini dapat dilihat dari data hasil pra survei pada tanggal 25 Juni 2012 pelajaran biologi kelas VIIA semester genap SMP Negeri 1 Gedung Aji Tahun Pelajaran 2011/2012.

Tabel 1. Data Hasil Ulangan Harian Siswa Kelas VIIA SMP Negeri 1 Gedung Aji Tahun Pelajaran 2011/2012

\begin{tabular}{c|c|c|c|c}
\hline No & Nilai & Krite ria & $\begin{array}{c}\text { Jumlah } \\
\text { Siswa }\end{array}$ & $\begin{array}{c}\text { Persentase } \\
(\boldsymbol{\%})\end{array}$ \\
\hline 1 & $<65$ & $\begin{array}{l}\text { Belum } \\
\text { Tercapai }\end{array}$ & 23 & 74,19 \\
\hline 2 & $\geq 65$ & Tercapai & 8 & 25,81 \\
\hline \multicolumn{2}{|c|}{ Jumlah } & 31 & 100 \\
\hline
\end{tabular}

Sumber data: Daftar nilai biologi kelas VIIA semester genap materi Ciri-Ciri Mahkluk Hidup Tahun Pelajaran 2011/2012.

Berdasarkan hasil wawancara dengan guru bidang studi biologi kelas VIIA SMP Negeri 1 Gedung Aji terkait dengan siswa yang belum mencapai nilai KKM (Kriteria Ketuntasan Minimal) yaitu 65, ditemukan beberapa keterampilan proses sains siswa yang sangat rendah yaitu:

1. Siswa yang mampu mengamati sebanyak 8 siswa atau $25,81 \%$ dari 31 siswa.

2. Siswa yang mampu mengajukan pertanyaan sebanyak 4 siswa atau $12,90 \%$ dari 31 siswa.
3. Siswa

yang

mampu mengkomunikasikan sebanyak 12 siswa atau $38,71 \%$ dari 31 siswa.

4. Siswa yang mampu menyimpulkan sebanyak 6 siswa atau 19,35\% dari 31 siswa.

Untuk meningkatkan keterampilan proses sains dan hasil belajar siswa diperlukan sebuah model pembelajaran yang mampu memberikan stimulus kepada siswa untuk terlibat aktif dalam proses pembelajaran. Oleh sebab itu, dengan melihat permasalahan-permasalahan di atas maka model pembelajaran experiential learning, dipandang relevan untuk mengatasi 
permasalahan tersebut. Model pembelajaran experiential learning adalah model pembelajaran yang menekankan kepada proses pengetahuan yang diciptakan melalui proses transformasi pengalaman guna meningkatkan keefektifan hasil belajar itu sendiri. Dan yang memuat langkah-langkah: pengalaman konkrit, pengamatan aktif dan reflektif, konseptualisasi, dan eksperimentasi aktif.

Menurut Baharuddin dan Wahyuni (2008:165) bahwa "experiential learning didefininsikan sebagai tindakan untuk mencapai sesuatu berdasarkan pengalaman yang secara terus-menerus mengalami perubahan guna meningkatkan keefektifan dari hasil belajar itu sendiri”. Menurut Uno (2008:15) prosedur pembelajaran dalam experiential learning berlangsung melalui 4 fase atau tahap yaitu:

a. Pengalaman konkrit; pada tahap ini seorang siswa hanya mampu sekedar ikut mengalami suatu kejadian. Siswa belum mempunyai kesadaran tentang hakikat kejadian tersebut. Siswa pun belum mengerti bagaimana dan mengapa suatu kejadian harus terjadi seperti itu.

b. Pengamatan aktif dan reflektif; siswa tersebut lambat laun mampu mengadakan observasi aktif terhadap kejadian itu, serta mulai berusaha memikirkan dan memahaminya.

c. Konseptualisasi; siswa mulai belajar untuk membuat abstraksi atau "teori" tentang sesuatu hal yang pernah diamatinya.

d. Eksperimentasi aktif; pada tahap akhir, siswa sudah mampu mengaplikasikan suatu aturan umum ke situasi baru.
Sesuai latar belakang masalah dan pendapat di atas, maka dapat dirumuskan permasalahan yaitu (1) Apakah pembelajaran biologi dengan menggunakan model pembelajaran experiential learning dapat meningkatkan keterampilan proses sains belajar siswa kelas VIIA SMP Negeri 1 Gedung Aji Tahun Pelajaran 2012/2013? (2) Apakah pembelajaran biologi dengan menggunakan model pembelajaran experiential learning dapat meningkatkan hasil belajar siswa kelas VIIA SMP Negeri 1 Gedung Aji Tahun Pelajaran 2012/2013?

Penelitian ini bertujuan (1) Untuk meningkatkan keterampilan proses sains belajar biologi siswa kelas VIIA SMP Negeri 1 Gedung Aji Tahun Pelajaran 2012/2013 dengan menggunakan model pembelajaran experiential learning. (2) Untuk meningkatkan hasil belajar biologi siswa kelas VIIA SMP Negeri 1 Gedung Aji Tahun Pelajaran 2012/2013 dengan menggunakan model pembelajaran experiential learning.

Manfaat penelitian adalah: (1) Bagi siswa, dapat meningkatkan keterampilan proses sains dan hasil belajar siswa. (2) Bagi guru dan calon guru, dapat menjadi model pembelajaran alternatif yang dapat diterapkan dalam pembelajaran biologi. (3) Bagi sekolah, dapat memberikan sumbangan yang berguna dalam upaya meningkatkan mutu pembelajaran di sekolah yang bersangkutan. (4) Bagi peneliti, dapat mengembangkan kemampuan melakukan penelitian.

\section{METODE}

Penelitian ini menggunakan rancangan PTK (Penelitian Tindakan Kelas), yang terdiri dari 4 tahapan 
yaitu perencanan, pelaksanaan, pengamatan, dan refleksi. Subjek penelitian adalah siswa kelas VIIA SMP Negeri 1 Gedung Aji Tahun Pelajaran 2012/2013, yang berjumlah 32 siswa. Penelitian berlangsung dua siklus, setiap siklus terdiri dari tiga kali pertemuan. Data keterampilan proses sains siswa diperoleh dengan menggunakan lembar observasi pada setiap pertemuan dan data hasil belajar siswa diperoleh dengan memberikan tes pada setiap akhir siklus. Penelitian dimulai pada tanggal 12 Januari 2013 sampai dengan 02 Februari 2013 dan setiap pertemuan alokasi waktu 2 x 40 menit.

\section{HASIL}

\section{Keterampilan Proses Sains Sis wa}

Tabe13. Data Hasil Observasi KPS Siswa Akhir Siklus I dan Akhir Siklus II

\begin{tabular}{|c|c|c|c|c|c|c|c|}
\hline \multirow[b]{2}{*}{ No } & \multirow[b]{2}{*}{ Aspek yang Diamati } & \multirow{2}{*}{\begin{tabular}{|c|} 
Pra \\
PTK \\
$(\%)$ \\
\end{tabular}} & \multirow{2}{*}{$\begin{array}{c}\text { Akhir } \\
\text { Siklus I } \\
(\%)\end{array}$} & \multirow{2}{*}{\begin{tabular}{|c|} 
Akhir \\
Siklus II \\
$(\%)$
\end{tabular}} & \multirow{2}{*}{$\begin{array}{c}\text { Target } \\
(\%)\end{array}$} & \multicolumn{2}{|c|}{ Ketercapaian } \\
\hline & & & & & & Siklus & Siklus II \\
\hline 1 & Mengamati & 25,81 & 88,89 & 97,22 & $\geq 90$ & $*$ & $\sqrt{ }$ \\
\hline 2 & Mengajukan pertanyaan & 12,90 & 46,88 & 63,89 & $\geq 40$ & $\sqrt{ }$ & $\sqrt{ }$ \\
\hline 3 & Mengkomunikasikan & 38,71 & 74,31 & 84,72 & $\geq 70$ & $\sqrt{ }$ & $\sqrt{ }$ \\
\hline 4 & Menyimpulkan & 19,35 & 72,22 & 85,76 & $\geq 70$ & $\sqrt{ }$ & $\sqrt{ }$ \\
\hline & umlah & & 282,30 & 331,59 & & & \\
\hline & Persentase (\%) & & 70,58 & 82,90 & & & \\
\hline & Rata-Rata (\%) & & \multicolumn{2}{|l|}{76,74} & & \multicolumn{2}{|r|}{$v$} \\
\hline & Kualifikasi & & \multicolumn{2}{|c|}{ Tinggi } & & & \\
\hline
\end{tabular}

Keterangan: (*) Belum Tercapai, Tercapai $(\sqrt{ })$

\section{Hasil Belajar}

Tabel 4. Data Hasil Belajar Siklus I dan Siklus II

\begin{tabular}{|c|l|l|l|l|l|l|l|l|}
\hline \multirow{2}{*}{ No } & \multirow{2}{*}{ Nilai } & \multicolumn{3}{|c|}{ Banyak Sis wa } & \multicolumn{3}{c|}{ Persentase (\%) } & \multirow{2}{*}{ Katagori } \\
\cline { 3 - 8 } & & Pra PTK & Siklus I & Siklus II & Pra PTK & Siklus I & Siklus II & \\
\hline 1 & $\geq 65$ & 8 & 25 & 28 & 25,81 & 78,13 & 87,50 & Tercapai \\
\hline 2 & $<65$ & 23 & 7 & 4 & 74,19 & 21,87 & 12,50 & Belu m Tercapai \\
\hline \multicolumn{2}{|l|}{ Jumlah } & 31 & 32 & 32 & 100 & 100 & 100 & \\
\hline
\end{tabular}

\section{PEMBAHASAN}

Peningkatan KPS siswa pada setiap akhir siklusnya disebabkan karena pembelajaran yang dilakukan sudah berjalan kondusif. Siswa sudah terbiasa melakukan keterampilan seperti: mengamati, mengajukan pertanyaan, mengkomunikasikan, dan menyimpulkan didukung dengan model pembelajaran experiential learning yang menuntut keaktifan siswa selama proses pembelajaran, karena dalam proses belajar siswa secara aktif berpikir tentang apa yang dipelajari dan kemudian menerapkan apa yang telah dipelajari dalam situasi nyata atau untuk menyelesaikan suatu masalah. Menurut Trianto (2010:144) bahwa: Keterampilan proses merupakan keseluruhan keterampilan ilmiah yang terarah (baik kognitif maupun psikomotor) yang dapat digunakan untuk menemukan suatu konsep atau prinsip atau teori, untuk 
mengembangkan konsep yang telah ada sebelumnya, ataupun melakukan penyangkalan terhadap suatu penemuan.

Menurut Baharuddin dan Wahyuni (2008:165) bahwa "model experiential learning menekankan pada keinginan kuat dari dalam siswa untuk berhasil dalam belajarnya". Menurut Munif (2009) bahwa: Model experiential learning memiliki kelebihan meningkatkan semangat dan gairah belajar, membantu terciptanya suasana belajar yang kond usif, memunculkan kegembiraan dalam proses belajar, mendorong dan mengembangkan proses berpikir kreatif, dan mendorong siswa untuk melihat sesuatu dari perspektif yang berbeda.

Meningkatnya hasil belajar siswa dari siklus I ke siklus II disebabkan karena adanya pengaruh dalam diri siswa yang termotivasi untuk belajar dengan usaha mengembangkan KPS yang dimilikinya selama proses pembelajaran. Oleh sebab itu, hasil belajar akan tercapai dengan baik apabila ada usaha dan motivasi untuk belajar. Sesuai dengan pendapat Keller (dalam Abdurrahman, 2003:39) bahwa: Hasil belajar adalah prestasi aktual yang ditampilkan anak, sedangkan usaha adalah perbuatan yang terarah pada penyelesaian tugas-tugas belajar yang berarti bahwa besarnya usaha adalah indikator dari adanya motivasi, sedangkan hasil belajar dipengaruhi oleh besarnya usaha yang dilakukan anak.

Selain itu, peningkatan KPS siswa dan hasil belajar terjadi karena siswa tertarik dan sudah terbiasa dengan model pembelajaran experiential learning dimana siswa semangat dalam bereksperimen dalam kelompok untuk membuktikan sebuah teori yang didukung dengan KPS sehingga suasana belajar lebih efektif dan menyenangkan. Hal ini sejalan dengan pendapat Baharuddin dan Wahyuni (2008:171) bahwa "experiential learning yang efektif akan mempengaruhi cara berpikir siswa, sikap dan nilai-nilai, persepsi, dan perilaku siswa".

\section{KESIMPULAN}

1. Penerapan model pembelajaran experiential learning dapat meningkatkan keterampilan proses sains siswa kelas VIIA SMP Negeri 1 Gedung Aji Tahun Pelajaran 2012/2013.

2. Penerapan model pembelajaran experiential learning dapat meningkatkan hasil belajar siswa kelas VIIA SMP Negeri 1 Gedung Aji Tahun Pelajaran 2012/2013.

\section{SARAN}

1. Bagi guru, untuk meningkatkan keterampilan proses sains dan hasil belajar siswa pada materi ciri-ciri mahkluk hidup, maka guru dapat menerapkan model pembelajaran experiential learning.

2. Bagi siswa, dapat menemukan sendiri konsep pengetahuan dan bersungguh-sungguh dalam melaksanakan pembelajaran serta melakukan keterampilan proses sains dengan baik agar hasil belajar yang diperoleh juga baik.

3. Bagi peneliti berikutnya, dapat menjadi acuan dalam mengembangkan kemampuan melakukan penelitian dan memberi masukan kepada peneliti selanjutnya terutama yang berkaitan dengan model 
pembelajaran experiential

learning.

\section{DAFTAR RUJUKAN}

Abdurrahman, M. 2003. Pendidikan

Bagi Anak Berkesulitan

Belajar. Jakarta: Rineka Cipta.

Baharuddin dan Wahyuni. 2008.

Teori Belajar \& Pembelajaran.

Jogjakarta: Ar Ruzz Media.

Munif, M. 2009. Jurnal Penetian

Fisika.

(online)

http://journal.unnes.ac.id.

Trianto. 2010. Mendesain Model

Pembelajaran Inovatif

Progresif. Jakarta: Kencana.

Uno, H. B. 2008. Model

Pembelajaran. Jakarta: Bumi Aksara. 